\title{
KETIDAKPATUHAN PAJAK PADA USAHA MIKRO, KECIL DAN MENENGAH
}

\author{
Erwin Rajagukguk ${ }^{1}$, Amrie Firmansyah ${ }^{2}$ \\ ${ }^{1,2}$ Politeknik Keuangan Negara STAN \\ Bintaro Utama Sektor V, Bintaro Jaya Tangerang Selatan, Banten \\ E-mail : amrie.firmansyah@gmail.com
}

\begin{abstract}
Organization for Economic Co-operation and Development-OECD (2012) states that all segments of Taxpayers, the Taxpayers of Small and Medium Enterprises (SMEs) have the highest non-compliance of all taxpayer segments in some countries. In Indonesia, SMEs have such a large number. In fact, almost $99 \%$ of the total national business actors are SMEs. This study examines the effect of Penalty Rate, Financial Liquidity, and Company Size on non-tax compliance. The sample used is the taxpayer of the SMEs on the Taxpayer Assessment Letter and the Annual Tax Return data obtained from the Directorate General of Tax in 2013.Using pusposive sampling, the selected sample of SMEs amounted to 155. The data are examined by multiple regression analysis using cross sectional data. The results show that penalty rate has no significant effect on non-compliance of SMEs taxpayer in Indonesia. The result is expected that the level of sanctions imposed on non-compliant taxpayers is still quite low in Indonesia. While financial liquidity has no significant effect on non-compliance of SMEs taxpayers in Indonesia. Furthermore, the company size has a significant negative effect on non-compliance of SMEs taxpayers in Indonesia.
\end{abstract}

Keywords: SMEs, Tax non-compliance

\section{PENDAHULUAN}

Penerimaan negara Indonesia saat ini sebagian besar ditopang dari penerimaan perpajakan. Namun dalam beberapa tahun belakangan ini terdapat tren penurunan realisasi penerimaan pajak ini dari tahun ke tahun. Untuk tahun 2015 sendiri realisasi penerimaan hanya sekitar $83 \%$ dari target yang sudah ditetapkan sebelumnya. Hal ini dipengaruhi oleh berbagai faktor dimana salah satunya adalah karena masih rendahnya kepatuhan para wajib pajak. Kepatuhan formal seperti penyampaian SPT Wajib Pajak saja masih berada di angka 50 sampai 60 persen saja.

Ketidakpatuhan wajib pajak masih menjadi masalah serius di banyak negara khususnya di negara berkembang seperti Indonesia. Masalah ketidakpatuhan ini jika dilihat dari segi penegakan hukum maka Direktorat Jenderal Pajak (DJP) selaku otoritas yang berwenang harus menerapkan hukum yang adil kepada semua Wajib Pajak Artinya apabila ditemukan Wajib Pajak yang tidak patuh seperti melalui pemeriksaan yang dilakukan oleh DJP maka harus dikenakan sanksi sesuai dengan ketentuan yang berlaku.

Salah satu tujuan pemeriksaan yang dilakukan oleh DJP di sini adalah untuk menguji kepatuhan pemenuhan kewajiban perpajakan dalam rangka memberikan kepastian hukum, keadilan, dan pembinaan kepada Wajib Pajak. Maka dari hasil pemeriksaan yang dilakukan oleh DJP ini apabila ditemukan koreksi yang menyebabkan penghasilan kena pajak yang meningkat maka dapat disimpulkan bahwa Wajib Pajak tersebut dikategorikan tidak patuh. Organisation for Economic Co-operation and Development-OECD (2012) menyatakan bahwa dari semua segmen Wajib Pajak, Wajib Pajak UMKM memiliki ketidakpatuhan yang paling tinggi dari semua segmen Wajib Pajak di beberapa 
negara. Di Indonesia sendiri jika dilihat dari segi jumlahnya, UMKM memiliki jumlah yang begitu besar. Bahkan hampir sekitar 99 Persen dari total pelaku usaha nasional merupakan UMKM. Berdasarkan data perkembangan Koperasi dan UMKM, jumlah koperasi pada tahun 2014 mencapai sebanyak 209.488 unit dan menyerap tenaga kerja sebanyak 567.445 orang. Sedangkan sektor UMKM pada tahun 2013 mencapai sebanyak 57.895.721 unit dan penyerapan tenaga kerja sebanyak 114.144.082 orang.

Selain itu dapat kita lihat juga kontribusi dari UMKM terhadap jumlah Produk Domestik Bruto (PDB) memiliki jumlah yang cukup signifikan yaitu mencapai angka di kisaran $60 \%$ jika dibandingkan terhadap total PDB Indonesia di tahun 2013. Juga merupakan penyumbang besar dalam penyerapan tenaga kerja. Fatkhurahman, F. (2016). Dengan melihat data ini maka dapat disimpulkan bahwa UMKM memegang peranan yang begitu besar dalam menumbuhkan perekonomian nasional seperti menyerap tenaga kerja, menggerakkan roda perekonomian, meningkatkan pembangunan, dan lain sebagainya. Penelitian terhadap ketidakpatuhan Wajib Pajak sudah cukup banyak dilakukan.

Penelitian

terhadap

ketidakpatuhan Wajib Pajak sudah cukup banyak dilakukan. Namun selama ini penelitian kebanyakan memfokuskan pada perilaku dari individunya itu sendiri. Masih jarang penelitian yang dilakukan terhadap wajib pajak badan khususnya UMKM. Terdapat beberapa penelitian yang sudah dilakukan terkait ketidakpatuhan ini dengan hasil yang bervariasi. Rice (1992) meneliti tentang faktor-faktor yang mempengaruhi kepatuhan perusahaan khususnya small corporation dengan menggunakan laporan pajak dari Tax Compliance
Measurement Program (TCMP) di Amerika. Hasil penelitiannya menunjukkan bahwa profitability perusahaan, ukuran perusahaan, dan perusahaan yang diatur secara ketat memiliki pengaruh yang positif dengan kepatuhan Wajib Pajak. Hanlon et al (2007) juga menganalisa data operasional dari Voluntary Compliance Baseline Measurement yang lebih update daripada data TCMP yang berakhir pada tahun 1998. Hanlon et al. menemukan bahwa perusahaan besar dan perusahaan domestik cenderung lebih patuh sedangkan perusahaan di bidang manufaktur, transportasi, perdagangan, pergudangan, pendidikan, dan kesehatan agak kurang patuh. Hasil penelitian mereka menunjukkan bahwa faktor-faktor seperti Penalty Rate, Likuiditas Keuangan, Ukuran Perusahaan dan Klasifikasi Lapangan Usaha (Types of Industry) memiliki pengaruh yang signifikan terhadap ketidakpatuhan perusahaan.

Penalty Rate merupakan Sanksi yang diberikan yang dapat berupa Denda, Bunga, maupun Kenaikan pajak yang harus dibayar sebagai akibat pelanggaran terhadap peraturan Undang-Undang Perpajakan. Sedangkan likuiditas keuangan merupakan kemampuan perusahaan dalam memenuhi kewajiban jangka pendeknya dan adapun ukuran perusahaan merupakan ukuran yang dipakai untuk mencerminkan besar kecilnya perusahaan yang didasarkan kepada total aset perusahaan (Suwito \& Herawaty, 2005).

Di Indonesia sendiri, penelitian terkait kepatuhan Wajib Pajak UMKM sudah pernah dilakukan beberapa kali seperti Oentari dan Mangoting (2013), Pamuji et al. (2014), Ananda et al. (2015) serta Inasius (2015). Namun penelitian itu hanya hanya mengulas persepi Wajib Pajak UMKM yang menggunakan data primer berupa kuesioner seperti pemahaman perpajakan, pandangan 


\section{Jurnal Ilmiah Ekonomi dan Bisnis}

Vol. 15. No. 2, September 2018: 110-121

EISSN : $2442-9813$

ISSN : $1829-9822$

terhadap sanksi, kualitas pelayanan petugas pajak dan berbagai variabel lainnya yang diperoleh secara langsung dari Wajib Pajak. Berbeda dengan penelitian tersebut, penelitian ini bertujuan untuk menguji ketidakpatuhan Wajib Pajak UMKM khususnya Wajib Pajak Badan dengan menggunakan data ketidakpatuhan yang aktual atau sebenarnya yang dilakukan oleh Wajib Pajak atas pemeriksaan yang telah dilakukan oleh Direktorat Jenderal Pajak dengan menerbitkan Surat Ketetapan Pajak Kurang Bayar (SKPKB). Ketidakpatuhan Wajib Pajak UMKM dalam penelitian ini diuji dengan Penalty Rate, Likuiditas Keuangan, dan Ukuran Perusahaan.

\section{TINJAUAN PUSTAKA}

Teori ini mengungkapkan bahwa Wajib Pajak membuat suatu keputusan untuk patuh tergantung pada atribut biaya dan keuntungan yang akan diperoleh terkait dengan kepatuhan pajak tersebut (Allingham \& Sandmo, 1972). Allingham dan Sandmo (1972) melakukan penelitian dengan tujuan untuk menganalisis keputusan dari wajib pajak apakah melakukan penghindaran pajak dan sejauh mana penghindaran tersebut dengan tidak melaporkan pajaknya. Keputusan pengungkapan pajak dari wajib pajak merupakan suatu keputusan yang berada dibawah ketidakpastian. Hal ini disebabkan karena apabila wajib pajak gagal atau tidak melaporkan semua penghasilannya yang sebenarnya tidak otomatis dikenakan sanksi. Karena alasan inilah wajib pajak mempunyai dua pilihan yaitu melaporkan semua penghasilannya yang sebenarnya atau bisa juga dengan melaporkan penghasilannya namun lebih sedikit dibanding penghasilan sebenarnya.

Jika wajib pajak memilih pilihan kedua yaitu hanya melaporkan sebagian dari penghasilannya maka hasilnya akan tergantung apakah wajib pajak tersebut diperiksa atau tidak. Jika benar diperiksa maka hasilnya bisa jadi lebih buruk.

Rice (1992) meneliti tentang faktor yang mempengaruhi kepatuhan perusahaan khususnya small corporation. Ia menggunakan laporan pajak dari Tax Compliance Measurement Program (TCMP) di Amerika. Hasil penelitiannya menunjukkan bahwa Profitability perusahaan, ukuran perusahaan, dan perusahaan yang diatur secara ketat memiliki pengaruh yang positif dengan kepatuhan Wajib Pajak. Namun Kamdar (1997) menemukan bahwa tidak ada bukti statistik yang menunjukkan bahwa kenaikan sanksi dan penurunan tarif pajak akan mengurangi ketidakpatuhan pajak.

$$
\text { Joulfaian dan Rider (1998) }
$$

melakukan penelitian dalam hal pola kepatuhan dari usaha kecil. Hasil penelitiannya menunjukkan bahwa Penghasilan, Marginal Tax Rate, dan kemungkinan terdeteksi memiliki hasil yang signifikan terhadap kepatuhan perusahaan. Kemudian di tahun 2000 Joulfaian juga melakukan penelitian yang menghasilkan kesimpulan bahwa semakin kecil Marginal Tax Rate, Rasio audit yang lebih tinggi, Ukuran perusahaan yang lebih besar, serta tingkat pendapatan memiliki pengaruh yang signifikan terhadap kepatuhan di Amerika.

Di Indonesia sendiri penelitian terhadap kepatuhan Wajib Pajak UMKM sudah beberapa kali dilakukan. Namun sepanjang pengetahuan Penulis belum ada satupun penelitian terhadap Wajib Pajak UMKM dengan menggunakan data sekunder atas pemeriksaan yang dilakukan kepada Wajib Pajak UMKM yang tidak patuh. Oleh karena itu, Penulis ingin meneliti terkait ketidakpatuhan Wajib Pajak Badan UMKM yang ada di Indonesia dengan menggunakan sample Wajib Pajak yang telah selesai diperiksa di tahun 2013 dengan bukti audit pemeriksaan pajak berupa dengan telah diterbitkannya Surat Ketetapan Pajak 
Kurang Bayar (SKPKB) kepada Wajib Pajak UMKM yang terbukti tidak patuh. Becker (1968) mengatakan bahwa seorang kriminal adalah mahluk yang rasional. Mereka akan memaksimalkan manfaat (utility) yang diperoleh walaupun dengan cara melawan hukum. Allingham dan Sandmo (1972) melakukan penelitian lanjutan dengan tujuan untuk menganalisis keputusan dari wajib pajak apakah melakukan penghindaran pajak dan sejauh mana penghindaran tersebut dengan tidak melaporkan pajaknya. Wajib Pajak membuat suatu keputusan untuk patuh tergantung pada atribut biaya dan keuntungan yang akan diperoleh terkait dengan kepatuhan pajak tersebut. Hasil penelitiannya menemukan bahwa terdapat hubungan yang positif antara penalty rate dengan penghasilan yang dilaporkan. Sedangkan Kamdar (1997) tidak menemukan bukti yang menyatakan bahwa kenaikan Penalty Rates akan mengurangi ketidakpatuhan. Walaupun masih terdapat ketidakkonsistenan hasil penelitian terhadap penalty ini namun salah satu tujuan dari pemberian sanksi adalah untuk memberi efek jera terhadap Wajib Pajak yang tidak patuh. Berdasarkan penelitian tersebut, maka hipotesis pertama dalam penelitian ini adalah sebagai berikut :

H1 : Penalty rate berpengaruh negatif terhadap ketidakpatuhan Wajib Pajak UMKM di Indonesia.

Likuiditas keuangan suatu perusahaan tentu akan berpengaruh terhadap setiap kebijakan yang akan diambil oleh perusahaan tersebut dalam menjalankan setiap aktivitasnya. Semakin tinggi tingkat likuiditas suatu perusahaan maka akan semakin baik pula kinerja dari perusahaan tersebut. Sebaliknya, semakin rendah tingkat likuiditas suatu perusahaan maka akan semakin buruklah kinerja dari perusahaan tersebut. Pada umumnya perusahaan yang memiliki likuiditas yang rendah akan cenderung untuk memanipulasi laporan keuangannya dengan menaikkan pendapatan maupun mengurangi beban untuk meningkatkan labanya. Spathis (2002) menemukan bahwa perusahaan dengan nilai working capital yang rendah akan lebih cenderung untuk memanipulasi laporan keuangannya untuk meningkatkan posisi keuangannya. OECD (2010) juga mengemukakan bahwa Wajib Pajak akan berkehendak untuk menghindari pajak untuk menghindari kekurangan kas. Berdasarkan penelitian tersebut, maka hipotesis kedua dalam penelitian ini adalah sebagai berikut :

H2 : Likuiditas keuangan berpengaruh negatif terhadap ketidakpatuhan Wajib Pajak UMKM di Indonesia.

Ukuran suatu perusahaan tentunya akan berpengaruh terhadap citra perusahaan itu sendiri. Pada umumnya semakin besar suatu perusahaan maka akan lebih diperhatikan oleh para investor. Karena para investor akan cenderung beranggapan bahwa perusahaan besar memiliki kondisi yang lebih stabil jika dibandingkan dengan perusahaan kecil. Apabila suatu perusahaan memiliki kondisi yang tidak stabil otomatis akan memiliki resiko yang lebih besar. Ketidakstabilan ini dapat memicu suatu perusahaan untuk melakukan suatu kecurangan dalam memulihkan kinerja perusahaan agar dapat stabil kembali di berbagai aspek dalam perusahaan tersebut. Tedds (2007) dan Nur-Tegin(2008) menemukan bahwa ukuran perusahaan berhubungan negatif dengan ketidakpatuhan Wajib Pajak. Perusahaan kecil akan lebih cenderung untuk menghindari pajak dibandingkan dengan perusahaan yang lebih besar. Hal ini bisa saja terjadi karena pada umumnya transaksi yang dilakukan oleh perusahaan kecil dalam bentus kas. Nur Tegin juga menyimpulkan bahwa perusahaan kecil lebih mudah untuk menyembunyikan 
Jurnal Ilmiah Ekonomi dan Bisnís

Vol. 15. No. 2, September 2018: 110-121

EISSN : $2442-9813$

ISSN : $1829-9822$

transaksinya. Di Indonesia sendiri Wajib Pajak UMKM ini jarang dilakukan pemeriksaan karena Pemeriksa Pajak cenderung untuk memeriksa Wajib Pajak yang lebih besar dan kadang-kadang biaya pemeriksaannya lebih besar dari penerimaan perpajakan yang dihasilkan. Rendahnya intensitas pemeriksaan ini dapat membuat Wajib Pajak menjadi tidak patuh. Berdasarkan penelitian tersebut, maka hipotesis ketiga dalam penelitian ini adalah sebagai berikut :

H3 : Ukuran perusahaan berpengaruh negatif terhadap ketidakpatuhan Wajib Pajak UMKM di Indonesia.

\section{METODE PENELITIAN}

Penelitian ini termasuk dalam penelitian kuantitatif yang menggunakan metode deskriptif kuantitatif untuk mengolah dan menganalisis data sehingga diperoleh kesimpulan berupa hubungan antara variabel yang diamati. Dalam penelitian ini model regresi linear berganda digunakan untuk melakukan analisis data sehingga dapat diketahui ada atau tidaknya pengaruh signifikan antara variabel independen terhadap variabel dependen dan arah hubungannya.

Pengambilan sampel dilakukan dari populasi yang ada dengan metode purposive sampling (judgement sampling) yang memilih sampel secara tidak acak dengan kriteria tertentu. Kriteria tersebut adalah sebagai berikut:

1. Wajib Pajak UMKM yang dilakukan pemeriksaan oleh Direktorat Jenderal Pajak yang mempunyai koreksi atau adjustment atas pemeriksaan yang dilakukan dengan diterbitkannya Surat Ketetapan Pajak Kurang Bayar (SKPKB) PPh Pasal 25/29 Badan di tahun 2013 atas tahun pajak 2012.

2. Usaha Mikro dengan kriteria memiliki penjualan tahunan paling banyak Rp300.000.000,00.
3. Usaha Kecil dengan kriteria memiliki penjualan tahunan lebih dari Rp300.000.000,00 sampai dengan paling banyak Rp2.500.000.000,00.

4. Usaha Menengah dengan kriteria memiliki penjualan tahunan lebih dari Rp2.500.000.000,00 sampai dengan paling banyak Rp50.000.000.000,00.

Penelitian ini menggunakan data sekunder. Data sekunder yang digunakan dalam penelitian ini berupa data Surat Ketetapan Pajak Kurang Bayar (SKPKB) dan data SPT Tahunan atas Wajib Pajak UMKM yang terjadi di tahun 2013. Data ini diperoleh dari Direktorat Jenderal Pajak.

Dalam penelitian ini variabel dependen adalah ketidakpatuhan pajak. Untuk mengukur ketidakpatuhan pajak dalam penelitian ini menggunakan proxy yang digunakan oleh Yusof et al. (2014) dengan menggunakan hasil koreksi pemeriksaan dibagi dengan total aset yang dimiliki sebagai berikut:

$Y=\frac{A D J}{A S S E T S}$

Dimana :

Y : Ketidakpatuhan Wajib Pajak

ADJ : Hasil koreksi pemeriksaan

ASSETS : Total Aset

Penalty Rate

Sanksi (Penalty) administrasi yang dikenakan terhadap Wajib Pajak terkait ketidakpatuhan yang dilakukannya terdiri atas tiga macam yaitu denda, bunga, atau kenaikan. Penalty rate dalam penelitian ini menggunakan proxy yang digunakan oleh Yusof et al. (2014) yaitu sebagai berikut :

Penalty Rate $=\frac{\Sigma \text { Penalty }}{\Sigma \text { Additional Taxes }}$

Dimana :

SPenalty : Total sanksi yang harus dibayarkan 
इAdditional Taxes: Total tambahan pajak yang tidak atau kurang bayar oleh WP

Likuiditas Keuangan

Likuiditas keuangan adalah kemampuan perusahaan dalam memenuhi kewajiban jangka pendeknya. Likuiditas keuangan dalam penelitian ini menggunakan proxy yang digunakan oleh Yusof et al. (2014) yaitu sebagai berikut :

Likuiditas Keuangan $=\frac{\Sigma \text { Current Assets }}{\text { ECurrent Liabilities }}$

Dimana :

ECurrent Assets : Total aset lancar yang dimiliki Wajib Pajak

¿Current Liabilities: Total kewajiban lancar yang dimiliki Wajib Pajak

Ukuran Perusahaan

Ukuran perusahaan (company size) pada dasarnya adalah pengelompokan perusahaan kedalam beberapa kelompok, diantaranya perusahaan besar, sedang dan kecil. Ukuran perusahaan dalam penelitian ini menggunakan proxy yang digunakan oleh Yusof et al. (2014) yaitu sebagai berikut:

Ukuran Perusahaan $=$ Ln Total Assets

Dimana:

Ln Total Assets : Logaritma natural dari Total Aset Wajib Pajak

Terdapat tiga variabel kontrol dalam penelitian ini yang dilihat dari Jenis Klasifikasi Lapangan usaha (KLU) dari WP Badan UMKM yang bersangkutan yaitu di bidang Manufaktur, Konstruksi, dan Perdagangan. Variabel kontrol dalam penelitian ini menggunakan proxy yang digunakan oleh Yusof et al. (2014) yaitu sebagai berikut :

a. DManufacturing : 1 Jika perusahaan termasuk dalam bidang Manufaktur, jika lainnya 0

b. DConstruction : 1 Jika perusahaan termasuk dalam bidang Konstruksi, jika lainnya 0

c. DWholesale \& Retail : 1 Jika perusahaan termasuk dalam bidang Perdagangan, jika lainnya 0

Variabel dependen dalam penelitian ini adalah ketidakpatuhan pajak yang diukur menggunakan hasil koreksi pemeriksaan yang dibagi total aset. Adapun variabel independen dalam penelitian ini yaitu Penalty Rate, Likuiditas Keuangan, dan Ukuran Perusahaan. Untuk meminimalkan pengaruh dari faktor-faktor yang dapat menimbulkan hasil penelitian yang bias, maka dalam penelitian ini digunakan pula variabel kontrol yaitu jenis bidang atau Klasifikasi Lapangan Usaha (KLU) dari Wajib Pajak yaitu dengan KLU Manufaktur, Konstruksi, dan Perdagangan.

Pengujian dilakukan dengan menggunakan regresi berganda untuk data cross sectional. Model penelitian yang akan digunakan dalam penelitian adalah sebagai berikut:

ADJ/Assets $=\beta_{0}+\beta_{1}$ Penalty Rate $+\beta_{2}$ Likuiditas Keuangan $+\beta_{3}$ Ukuran Perusahaan $+\beta_{4}$ DManufacturing $+\beta_{5}$ DConstruction $+\beta_{6}$ DWholesale\&Retail Trade $+\varepsilon$

Dimana :

$\begin{array}{llr}\text { ADJ/Assets }= & \text { Koreksi/Adjustme } \\ & n t \quad \text { pemeriksaan } \\ & \text { dibagi dengan } \\ & \text { total } & \text { aset } \\ & \text { (Variabel } & \\ \text { Penalty Rate }= & \text { Dependen) } & \\ & \text { Ratio } & \text { jumlah } \\ & \text { sanksi } & \text { dibagi } \\ & \text { dengan } & \\ & \text { pengenaan } & \text { pajak } \\ & \text { tambahan }\end{array}$


Jurnal Ilmiah Ekonomí dan Bísnis

Vol. 15. No. 2, September 2018: 110-121

EISSN : $2442-9813$

ISSN : $1829-9822$

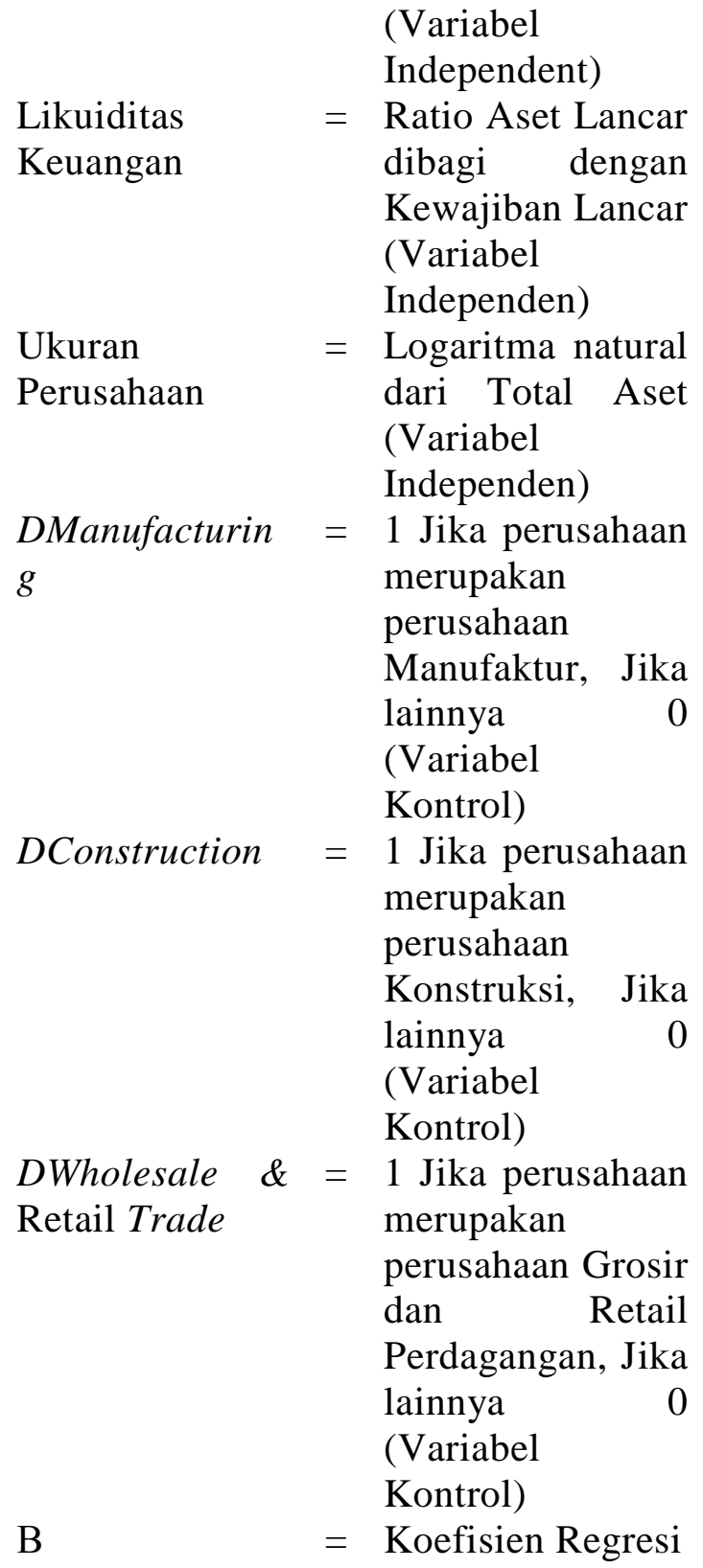

\section{HASIL DAN PEMBAHASAN}

Sampel dalam penelitian ini dipilih dengan menggunakan purposive sampling. Dengan purposive sampling data diambil menggunakan kriteria yang telah ditentukan sebelumnya. Kriteria pertama adalah Wajib Pajak merupakan UMKM dimana Wajib Pajak tersebut memiliki penjualan tahunan atau omset mulai dari Rp. 300.000.000,00 s.d Rp. 50.000.000.000,00. Kriteria kedua adalah Wajib Pajak tersebut dilakukan pemeriksaan oleh Direktorat Jenderal Pajak dan mempunyai koreksi atau adjustment atas pemeriksaan yang dilakukan dengan diterbitkannya Surat Ketetapan Pajak Kurang Bayar (SKPKB) PPh Pasal 25/29 Badan di tahun 2013 atas tahun pajak 2012. Dari hasil pemilihan sampel ditemukan 155 Wajib Pajak yang sesuai dengan kriteria yang telah ditentukan (purposive sampling).

Nilai minimum dan maksimum untuk ketidakpatuhan Wajib Pajak UMKM (Y) adalah sebesar 0.00000197 dan 7.15. Nilai minimum dan maksimum untuk Penaty Rate adalah sebesar 0.09 dan 0.27. Nilai minimum dan maksimum untuk Likuiditas Keuangan adalah sebesar 0.06 dan 2.68. Nilai minimum dan maksimum untuk Ukuran Perusahaan adalah sebesar 16.65 dan 25.12.

Nilai Ketidakpatuhan Wajib Pajak UMKM (Y) memiliki nilai rata-rata sebesar 0.21. Variabel Independen Penalty Rate memiliki rata-rata 0.17 . Nilai rata-rata Penalty Rate yang hanya sebesar 0.17 mengindikasikan bahwa Direktorat Jenderal Pajak mengenakan sanksi yang rendah ketika pemeriksa pajak menemukan ketidakpatuhan Wajib Pajak selama proses pemeriksaan. Nilai rata-rata untuk likuiditas keuangan adalah sebesar 0.89 (berdasarkan current ratio Wajib Pajak UMKM). Hasil ini mengindikasikan bahwa Wajib Pajak UMKM tidak mempunyai likuiditas keuangan yang kuat sehingga dikhawatirkan dapat menimbulkan masalah dalam pembayaran utang maupun kewajiban pajak dari Wajib Pajak UMKM tersebut. Nilai rata-rata untuk ukuran perusahaan adalah sebesar 20.82. Nilai ini diperoleh dari hasil logaritma natural dari total aset. Nilai yang semakin besar berarti mengindikasikan bahwa ukuran perusahaan tersebut semakin besar dan jumlah aset yang dimiliki semakin banyak pula. 
Tabel 1. Analisis statistik deskriptif

\begin{tabular}{|c|c|c|c|c|c|c|c|}
\hline & $\mathrm{Y}$ & $\begin{array}{l}\text { Pena } \\
\text { lty } \\
\text { Rate }\end{array}$ & $\begin{array}{l}\text { Likui } \\
\text { ditas } \\
\text { Keua } \\
\text { ngan }\end{array}$ & $\begin{array}{l}\text { Ukura } \\
\text { nn } \\
\text { Perus } \\
\text { ahaan }\end{array}$ & $\begin{array}{l}\text { Konst } \\
\text { ruksi }\end{array}$ & $\begin{array}{l}\text { Manu } \\
\text { faktur }\end{array}$ & $\begin{array}{l}\text { Perdag } \\
\text { angan }\end{array}$ \\
\hline $\begin{array}{l}\text { Mea } \\
\text { n }\end{array}$ & $\begin{array}{r}0.21 \\
9103\end{array}$ & $\begin{array}{r}0.17 \\
4692 \\
\end{array}$ & $\begin{array}{r}0.89 \\
6852 \\
\end{array}$ & $\begin{array}{r}20.8 \\
2541 \\
\end{array}$ & $\begin{array}{r}0.18 \\
0645 \\
\end{array}$ & $\begin{array}{l}0.129 \\
032\end{array}$ & $\begin{array}{l}0.432 \\
258\end{array}$ \\
\hline $\begin{array}{l}\text { Medi } \\
\text { an }\end{array}$ & $\begin{array}{r}0.01 \\
2016 \\
\end{array}$ & $\begin{array}{r}0.18 \\
0328 \\
\end{array}$ & $\begin{array}{r}1.00 \\
0000\end{array}$ & $\begin{array}{r}20.7 \\
0586 \\
\end{array}$ & $\begin{array}{r}0.00 \\
0000\end{array}$ & $\begin{array}{c}0.000 \\
000\end{array}$ & $\begin{array}{c}0.000 \\
000\end{array}$ \\
\hline $\begin{array}{l}\text { Maxi } \\
\text { mum }\end{array}$ & $\begin{array}{r}7.15 \\
3145\end{array}$ & $\begin{array}{r}0.27 \\
5362\end{array}$ & $\begin{array}{r}2.68 \\
2357\end{array}$ & $\begin{array}{r}25.1 \\
2304\end{array}$ & $\begin{array}{c}1.00 \\
0000\end{array}$ & $\begin{array}{c}1.000 \\
000\end{array}$ & $\begin{array}{c}1.000 \\
000\end{array}$ \\
\hline $\begin{array}{l}\text { Mini } \\
\text { mum }\end{array}$ & $\begin{array}{r}1.97 \\
\text { E-06 } \\
\end{array}$ & $\begin{array}{r}0.09 \\
0909 \\
\end{array}$ & $\begin{array}{r}0.06 \\
5341 \\
\end{array}$ & $\begin{array}{r}16.6 \\
5605 \\
\end{array}$ & $\begin{array}{r}0.00 \\
0000 \\
\end{array}$ & $\begin{array}{c}0.000 \\
000\end{array}$ & $\begin{array}{c}0.000 \\
000\end{array}$ \\
\hline $\begin{array}{l}\text { Std. } \\
\text { Dev. }\end{array}$ & $\begin{array}{r}0.79 \\
1481\end{array}$ & $\begin{array}{r}0.02 \\
9107\end{array}$ & $\begin{array}{r}0.26 \\
9157\end{array}$ & $\begin{array}{r}1.97 \\
6237\end{array}$ & $\begin{array}{r}0.38 \\
5971\end{array}$ & $\begin{array}{c}0.336 \\
322\end{array}$ & $\begin{array}{l}0.496 \\
996\end{array}$ \\
\hline
\end{tabular}

intinya digunakan untuk mengukur seberapa jauh kemampuan model dalam menerangkan variasi variabel dependen. Dari Tabel 2. dapat dilihat bahwa nilai $\mathrm{R}^{2}$ adalah sebesar 0.059130. Hal ini menunjukkan bahwa variasi ketidakpatuhan Wajib Pajak UMKM dapat dijelaskan oleh variabel Penalty Rate, Likuiditas Keuangan, Ukuran Perusahaan dengan adanya variabel kontrol berupa jenis Klasifikasi Lapangan Usaha (KLU) dari Wajib Pajak yaitu Konstruksi, Manufaktur, dan Perdagangan hanya sebesar $5.913 \%$. Sedangkan sisanya sebesar $94.087 \%$ dijelaskan oleh faktor-faktor lain di luar model penelitian. Kecilnya nilai $\mathrm{R}^{2}$ juga dipengaruhi data observasi yang berupa data cross section. Secara umum koefisien determinasi untuk data silang (cross section) relatif rendah. Hal ini disebabkan karena adanya variasi yang besar antara masing-masing pengamatan, sedangkan untuk data runtun waktu (time series) biasanya mempunyai nilai koefisien determinasi yang tinggi (Ghozali, 2013).

Tabel 2. Koefisien Determinasi

\begin{tabular}{|c|c|c|c|}
\hline uared & 0.095788 & $\begin{array}{l}\text { Mean } \\
\text { dependent var }\end{array}$ & 0.219103 \\
\hline $\begin{array}{ll}\text { Adjusted } & \mathrm{R} \\
\text { squared }\end{array}$ & 0.05913 & $\begin{array}{l}\text { S.D. } \\
\text { dependent var }\end{array}$ & 0.79148 \\
\hline
\end{tabular}

Sumber : Data sekunder yang diolah

Uji F dilakukan untuk mengetahui pengaruh secara simultan variabel dalam penelitian terhadap ketidakpatuhan pajak. Tabel 3. memaparkan hasil Uji $\mathrm{F}$ menggunakan aplikasi EViews versi 9. Berdasarkan data tersebut didapatkan nilai Prob(F- statistic) sebesar 0.019485. Nilai ini berada dibawah batas signifikansi sebesar 0,05 . Oleh karena itu dapat diartikan bahwa secara bersama-sama atau simultan variabel dalam penelitian ini berpengaruh signifikan terhadap ketidakpatuhan pajak.

Tabel 3. Uji F

F-statistic 2.613061stat

2.021524

$\operatorname{Prob}(\mathrm{F}-$

statistic) $\quad 0.019485$

Sumber : Data sekunder yang diolah

Uji statistik $t$ dalam penelitian ini digunakan untuk menunjukkan seberapa jauh pengaruh variabel independen dalam menerangkan variasi variabe dependen. Untuk menentukan hasil uji t, dilakukan dengan melihat nilai probability pada masing-masing variabel independen. Jika nilainya lebih kecil dari pada nilai $\alpha$ yaitu 0.05 maka $\mathrm{H} 0$ ditolak atau dengan kata lain variabel independen secara parsial berpengaruh secara signifikan terhadap variabel independen dan berlaku juga sebaliknya.

Berdasarkan hasil uji t pada tabel 4.5, dari tiga variabel independen dalam model regresi dengan tingkat signifikansi 5\% dapat disimpulkan bahwa variabel Penalty Rate dan Likuiditas Keuangan berpengaruh tidak signifikan terhadap variabel ketidakpatuhan Wajib Pajak UMKM sedangkan variabel Ukuran Perusahaan berpengaruh signifikan terhadap variabel ketidakpatuhan Wajib Pajak UMKM.

Tabel 4. Hasil Uji t

\begin{tabular}{|c|c|c|c|c|c|}
\hline Variable & Coefficient & Std. Error & t-Statistic & Prob. & Signifikansi \\
\hline $\begin{array}{c}\text { Penalty Rate } \\
\text { Likuiditas } \\
\text { Keuangan }\end{array}$ & 2.272481 & 2.147882 & 1.05801 & 0.2918 & Tidak \\
\hline $\begin{array}{c}\text { Ukuran } \\
\text { Perusahaan }\end{array}$ & -0.116667 & 0.246287 & -0.473704 & 0.6364 & Tidak \\
\hline Konstruksi & -0.285418 & 0.192299 & -1.484239 & 0.1399 & Tidak \\
\hline Manufaktur & -0.091759 & 0.233415 & -0.393116 & 0.6948 & Tidak \\
\hline Perdagangan & -0.097594 & 0.155634 & -0.627076 & 0.5316 & Tidak \\
\hline
\end{tabular}

Sumber : Data sekunder yang diolah

Dari Tabel 4. di atas dapat diketahui sebagai berikut : 
Jurnal Ilmiah Ekonomi dan Bisnís

Vol. 15. No. 2, September 2018: 110-121

EISSN : $2442-9813$

ISSN : $1829-9822$

Hipotesis 1: Pengaruh penalty rate terhadap ketidakpatuhan pajak.

Nilai $p$ value dari penalty rate adalah sebesar 0.2918. Karena nilai $p$ value lebih dari 0,05 maka penalty rate tidak signifikan pengaruhnya terhadap ketidakpatuhan pajak.

Hipotesis 2 : Pengaruh likuiditas keuangan terhadap ketidakpatuhan pajak.

Nilai $p$ value dari likuiditas keuangan adalah sebesar 0.6364. Karena nilai $p$ value lebih dari 0,05 maka likuiditas keuangan tidak signifikan pengaruhnya terhadap ketidakpatuhan pajak.

Hipotesis 3 : Pengaruh ukuran perusahaan terhadap ketidakpatuhan pajak.

Nilai $p$ value dari ukuran perusahaan adalah sebesar 0.0007. Karena nilai p value kurang dari 0,05 maka ukuran perusahaan berpengaruh signifikan terhadap agresivitas pajak. $P$ value juga bernilai positif sehingga dapat dinyatakan bahwa ukuran perusahaan berpengaruh positif terhadap ketidakpatuhan pajak.

Pengaruh penalty rate terhadap ketidakpatuhan pajak

Dengan adanya sanksi yang diberlakukan atas setiap pelanggaran ketentuan perpajakan yang dilakukan oleh Wajib Pajak, diharapkan para Wajib Pajak dapat lebih jujur dan patuh dalam memenuhi setiap kewajiban perpajakannya masing-masing. Pengenaan sanksi perpajakan ini juga diharapkan dapat membuat Wajib Pajak lebih gentar apabila melakukan pelanggaran dalam pemenuhan kewajiban perpajakannya. Jadi seiring dengan makin tinggi atau beratnya sanksi yang diberikan diharapkan ketidakpatuhan Wajib Pajak dapat menurun. Akan tetapi, hasil penelitian ini menunjukkan kesimpulan yang berbeda dengan hipotesis dan teori tersebut.

Dari hasil pengujian diatas penalty rate tidak berpengaruh terhadap ketidakpatuhan pajak. Hasil penelitian ini menunjukkan bahwa besar kecilnya sanksi yang diberikan kepada Wajib Pajak UMKM tidak mempengaruhi peningkatan maupun penurunan ketidakpatuhan Wajib Pajak. Hasil penelitian ini sejalan dengan penelitian yang dilakukan oleh Oladipupo dan Obazee (2016) yang juga menyatakan bahwa penalty rate tidak berpengaruh signifikan terhadap ketidakpatuhan Wajib Pajak. Hal ini dimungkinkan karena tingkat sanksi yang dikenakan terhadap Wajib Pajak yang tidak patuh masih cukup rendah. Rendahnya sanksi yang diberikan tidak membuat Wajib Pajak UMKM di Indonesia menjadi lebih takut ataupun menjadi lebih berani untuk melakukan ketidakpatuhan perpajakan.

\section{Pengaruh likuiditas keuangan terhadap ketidakpatuhan pajak}

Secara umum likuiditas digunakan untuk menunjukkan posisi keuangan atau kekayaan sebuah entitas. Dengan mengetahui tingkat likuiditas suatu entitas maka akan lebih mudah untuk mengambil keputusan yang terkait dengan segala kegiatan yang berhubungan dengan entitas tersebut. Semakin tinggi likuiditas suatu entitas maka akan semakin baik pula kinerja dari entitas tersebut. Begitu juga sebaliknya, semakin rendah tingkat likuiditas suatu entitas maka semakin buruk kinerja dari entitas tersebut. Rendahnya likuiditas yang dimiliki suatu entitas dapat memacu entitas tersebut untuk melakukan pelanggaran seperti memanipulasi laporan keuangannya. Rendahnya tingkat likuiditas ini tentunya juga akan mempengaruhi entitas tersebut dalam memenuhi kewajiban perpajakannya. Rendahnya tingkat likuiditasnya tersebut dapat membuat entitas tersebut lebih mengutamakan sumber daya yang dimiliki untuk 
keberlangsungan kegiatan utama dari entitas tersebut dan mengesampingkan kewajiban perpajakannya.

Dari hasil pengujian diatas likuiditas keuangan tidak berpengaruh secara signifikan terhadap ketidakpatuhan yang dilakukan oleh Wajib Pajak UMKM. Hasil penelitian ini menunjukkan bahwa besar kecilnya tingkat likuiditas yang dimiliki oleh Wajib Pajak UMKM tidak mempengaruhi peningkatan maupun penurunan pada ketidakpatuhan Wajib Pajak UMKM tersebut. Hasil penelitian ini sejalan dengan penelitian yang dilakukan oleh Yusof et al (2014) yang juga menyatakan bahwa likuiditas keuangan tidak berpengaruh signifikan terhadap ketidakpatuhan Wajib Pajak. Dalam Pasal 4 ayat 2 PMK 17/PMK.03/2013 disebutkan bahwa salah satu kriteria pengujian kepatuhan pemenuhan kewajiban perpajakan adalah terhadap Wajib Pajak yang menyampaikan surat pemberitahuan yang menyatakan rugi. Ternyata kriteria ini tidak sesuai dengan hasil temuan dalam penelitian ini dimana ditemukan bahwa Wajib Pajak UMKM yang tidak patuh di Indonesia didominasi oleh perusahaan yang menghasilkan keuntungan.

Pengaruh ukuran perusahaan terhadap ketidakpatuhan pajak

Ukuran

mencerminkan besar kecilnya perusahaan yang didasarkan kepada total aset perusahaan. Semakin besar aset suatu perusahaan maka semakin besar pula ukuran suatu perusahaan. Seiring dengan membesarnya ukuran suatu perusahaan, ada kecenderungan bahwa perusahaan tersebut akan lebih diperhatikan oleh para investor. Hal ini disebabkan karena perusahaan besar cenderung lebih memiliki kondisi yang stabil dibandingkan dengan perusahaan yang memiliki ukuran yang lebih kecil.
Besarnya jumlah aset yang dimiliki serta kondisi stabil tersebut tentunya akan membuat Wajib Pajak lebih patuh dalam memenuhi kewajiban perpajakannya.

Dari hasil pengujian diatas ukuran perusahaan memiliki pengaruh yang signifikan terhadap ketidakpatuhan Wajib Pajak UMKM. Karena koefisien yang memberikan tanda negatif maka dapat disimpulkan bahwa ukuran perusahaan berpengaruh negatif terhadap ketidakpatuhan Wajib Pajak. Pengaruh negatif yang signifikan ukuran perusahaan terhadap ketidakpatuhan Wajib Pajak UMKM dalam penelitian ini berarti bahwa adanya kenaikan dalam ukuran perusahaan akan menyebabkan penurunan dalam ketidakpatuhan Wajib Pajak UMKM. Begitu juga sebaliknya adanya penurunan dalam ukuran suatu perusaan akan menyebabkan adanya kenaikan dalam ketidakpatuhan Wajib Pajak tersebut.

Hasil penelitian ini sejalan dengan penelitian Yusof et al. (2014). Perusahaan yang lebih besar lebih patuh dimungkinkan karena perusahaan tersebut memiliki internal kontrol yang lebih baik, sistem akuntansi yang lebih baik, dan tata kelola perusahaan yang lebih baik dibandingkan dengan perusahaan yang lebih kecil. Namun hasil penelitian ini berbeda dengan politycal cost theory yang menyatakan bahwa perusahaan besar yang masuk bursa cenderung untuk melakukan ketidakpatuhan perpajakan. Hal ini dapat terjadi karena perusahaan besar tersebut lebih memiliki kemampuan dalam melakukan manajemen laba maupun dalam memilih metode akuntansi yang digunakan. Sedangkan perusahaan kecil kurang memiliki kemampuan dalam penerapan manajemen laba maupun dalam pemilihan metode akuntansi yang digunakan.

\section{KESIMPULAN DAN SARAN}

Berdasarkan hasil dan pembahasan yang dilakukan sebelumnya dapat diambil 
Jurnal Ilmiah Ekonomi dan Bisnis

Vol. 15. No. 2, September 2018: 110-121

EISSN : $2442-9813$

ISSN : $1829-9822$

kesimpulan sebagai berikut : Penalty rate tidak berpengaruh terhadap ketidakpatuhan pajak Wajib Pajak UMKM. Likuiditas Keuangan tidak berpengaru terhadap ketidakpatuhan pajak Wajib Pajak UMKM. Ukuran perusahaan berpengaruh negatif signifikan terhadap ketidakpatuhan pajak Wajib Pajak UMKM. Hal ini menunjukkan bahwa terjadi hubungan yang terbalik antara ukuran perusahaan dan ketidakpatuhan Wajib Pajak UMKM sehingga apabila terjadi kenaikan pada Ukuran Perusahaan maka akan terjadi pula penurunan pada ketidakpatuhan pajak Wajib Pajak UMKM tersebut.

Untuk penelitian selanjutnya dapat memperluas objek penelitian seperti memperluas sampel tidak hanya Wajib Pajak UMKM sehingga diharapkan dapat memberi hasil yang lebih komprehensif yang dapat menggambarkan kondisi ketidakpatuhan Wajib Pajak di Indonesia, serta dapat menambah rentang waktu penelitian.

Untuk Direktorat Jenderal Pajak harus lebih memperberat sanksi yang dikenakan terhadap Wajib Pajak yang tidak patuh. Hal ini dikarenakan Wajib Pajak masih terlalu sering melakukan tindakan spekulasi untuk tidak patuh karena menganggap sanksinya tidak terlalu berat. Direktorat Jenderal Pajak harus bisa menciptakan efek takut yang luar biasa bagi Wajib Pajak yang terbukti melakukan ketidakpatuhan dalam pemenuhan kewajiban perpajakannya. Selain itu Direktorat Jenderal Pajak juga harus mempublikasikan para Wajib Pajak yang tidak patuh tersebut ke media untuk memberi efek jera dan sebagai peringatan kepada Wajib Pajak lainnya.

Direktorat Jenderal Pajak juga harus bisa mengeluarkan suatu kebijakan yang membuat UMKM lebih patuh seperti dengan memberi suatu insentip atau skema pengenaan perpajakan yang lebih mudah dan juga harus membantu UMKM dalam pengembangan usahanya. Selain itu, Direktorat Jenderal Pajak dalam melakukan pemeriksaan terhadap Wajib Pajak UMKM dapat lebih memfokuskan pemeriksaan terhadap Wajib Pajak dengan Klasifikasi Lapangan Usaha (KLU) di bidang perdagangan dan jasa yang telah terbukti sebagai KLU yang paling banyak melakukan ketidakpatuhan.

Berdasarkan penelitian yang dilakukan, terdapat keterbatasan penelitian sebagai berikut : Penelitian ini hanya memfokuskan untuk Wajib Pajak UMKM yang dilakukan pemeriksaan oleh Direktorat Jenderal Pajak yang mempunyai koreksi atau adjustment atas pemeriksaan yang dilakukan dengan diterbitkannya Surat Ketetapan Pajak Kurang Bayar (SKPKB) PPh Pasal 25/29 Badan. Surat Ketetapan Pajak Kurang Bayar (SKPKB) diterbitkan oleh Direktorat Jenderal Pajak setiap tahun berbeda jumlah dan WPnya sehingga sulit untuk membuat data yang lebih dari satu tahun.

\section{DAFTAR PUSTAKA}

Allingham, M. G., \& Sandmo, A. (1972). Income tax evasion: a theoretical analysis. Journal of Public Economics, 1(3-4), 323-338.

Ananda, P. R. D., Kumadji, S., \& Husaini, A. (2015). Pengaruh sosialisasi perpajakan, tarif pajak, dan pemahaman perpajakan terhadap kepatuhan wajib pajak (Studi pada UMKM yang Terdaftar sebagai Wajib Pajak di Kantor Pelayanan Pajak Pratama Batu). Jurnal Perpajakan, 6(2).

Fatkhurahman, F. (2016). Kepuasan Berwirusaha Melalui Kemauan Untuk Berkarya Usaha Industri Kecil. Jurnal Ekonomi dan Bisnis Islam UIN Imam Bonjol, 1(2), 143153.

Ghozali, I. (2013). Aplikasi analisis multivariate dengan program ibm 
Jurnal Ilmiah Ekonomi dan Bísnis

Vol. 15. No. 2, September 2018: 110-121

EISSN : $2442-9813$

ISSN : $1829-9822$

dan spss. In aplikasi analisis multivariate dengan program ibm spss 21. Badan Penerbit Universitas Diponegoro

umkm di kpp pratama malang selatan). Fakultas Ilmu Administrasi Universitas Brawijaya, 1-9.

Hanlon, M., Mills, L., \& Slemrod, J. (2005). An empirical examination of corporate tax non-compliance (Working Paper), University of Michigan.

Joulfaian, D. (2000). Corporate income tax evasion and managerial preferences. Review of Economics and Statistics, (1991), 4-7.

Kamdar, N. (1997). Corporate income tax compliance: A time series analysis. Atlantic Economic Journal, 25(1), 37-49.

Nur-tegin, K. D. (2008). Determinants of Business Tax Compliance. The B.E. Journal of Economic Analysis \& Policy, 8(1).

OECD. (2010). Understanding and Influencing Taxpayers' Compliance Behaviour. Forum on Tax Administration: SME Compliance Sub-Group, (November), 1-49.

Oentari, A., \& Mangoting, Y. (2013). Pengaruh kualitas pelayanan petugas pajak, sanksi perpajakan dan biaya kepatuhan pajak terhadap kepatuhan wajib pajak umkm. Tax \& Accounting Review, 1, 18-27.

Pamuji, A.R., Mukzam, M.D., \& Sudjana, N. (2014). Faktor-faktor yang mempengaruhi kepatuhan pemilik usaha mikro, kecil, dan menengah (umkm) dalam memenuhi kewajiban perpajakan (studi pada wajib pajak pemilik 